\title{
Antioxidant capacity of egg, milk and soy protein hydrolysates and biopeptides produced by Bromelia pinguin and Bromelia karatas-derived proteases
}

\author{
Libier Meza-Espinoza1, Sonia Guadalupe Sáyago-Ayerdi', Maria de Lourdes García-Magaña', \\ Erik Gustavo Tovar-Pérez',2, Elhadi M. Yahia ${ }^{3}$, Belinda Vallejo-Cordoba ${ }^{4}$, Aarón F. González-Córdova ${ }^{4}$, \\ Adrian Hernández-Mendoza ${ }^{4}$, Efigenia Montalvo-González ${ }^{1 *}$ \\ ${ }^{1}$ Laboratorio Integral de Investigación en Alimentos, Instituto Tecnológico de Tepic, Tepic, Nayarit, México, ${ }^{2}$ Consejo Nacional de Ciencia y \\ Tecnología-Instituto Tecnológico de Tepic, Tepic, Nayarit, México, ${ }^{3}$ Facultad de Ciencias Naturales, Universidad Autónoma de Querétaro, \\ Querétaro, México, ${ }^{4}$ Centro de Investigación en Alimentación y Desarrollo A.C., Hermosillo, Sonora, Mexico
}

\section{A B S T R A C T}

Given the lack of knowledge in the generation and biological activity of biopeptides (BP) produced by Bromelia pinguin and Bromelia karatas-derived proteases, the objective of this work was to evaluate the antioxidant capacity (AOX) of protein hydrolysates and peptide fractions from hydrolysis of egg, milk and soy proteins with enzymes extracted from Bromelia pinguin and Bromelia karatas fruits. The degree of hydrolysis $(\mathrm{DH})$ of the mentioned proteins was measured. The hydrolysates were sequentially fractionated by ultrafiltration using different membrane pore sizes $(\leq 30, \leq 10, \leq 5$ and $\leq 1 \mathrm{kDa}$ ) to obtain biopeptide fractions (BPF). The antioxidant capacity (AOX) of protein hydrolysates and BPF were evaluated. AOX was performed using 2,2' -azinobis-(3-ethylbenzothiazoline-6-sulfonic acid) (ABTS $\left.{ }^{+}\right)$, ferric reducing antioxidant power (FRAP) and oxygen radical absorbance capacity (ORAC) assays. after the enzymatic action of $B$. pinguin and $B$. karatas proteases, the highest DH values for egg, milk and soy protein hydrolysates ranged from $50-61 \%, 55-68 \%$ and $73-81 \%$, respectively. The AOX was higher for soy hydrolysates than for egg and milk hydrolysates. Additionally, the highest AOX from ABTSand FRAP assays was observed for $\mathrm{BPF} \leq 30 \mathrm{kDa}, \mathrm{PF} \leq 5 \mathrm{kDa}$ and $\leq 1 \mathrm{kDa}$, respectively. These results highlight the potential of $B$. pinguin and $B$. karatas proteases to hydrolyze food proteins and release bioactive peptides. Moreover, it has been shown that the hydrolysis products are a mixture of BP of different molecular weights, which could present AOX through different mechanisms.

Keywords: Antioxidant capacity; Hydrolysates; Biopeptides; Bromelia karatas; Bromelia pinguin; Proteases

\section{INTRODUCTION}

Food proteins have received a particular attention in the human nutrition. During protein hydrolysis may be liberated biopeptides or bioactive peptides (BP) exhibiting biological activity. The bioactive peptides (BP), are usually generated in vivo by the action of the gastrointestinal enzymes, but may also be obtained in vitro with plant and microbial proteases, and generated during food processing (Sila and Bougatef, 2016).

$\mathrm{BP}$ interfere in the metabolic regulation and modulation, and they are used as potential nutraceutics and as ingredients of functional foods. Also, they present important properties such as antioxidants, chelators, anticoagulant, antimicrobial, hypocholesterolemic, growth stimulating of probiotic bacteria and antihypertensive (Sun et al., 2014; Zeineb et al., 2015; Przybylski et al., 2016; Sabbione et al., 2016; Marques et al., 2015; Titov et al., 2016; Lafarga et al., 2016).

The most studied biological activity in BP is the antioxidant capacity (AOX). The oxidative stress cause pathophysiological effects such as degenerative diseases, tissue damage and metabolic syndrome (Santilli et al., 2015; Azofeifa et al., 2016). Due to the different adverse effects caused by reactive oxygen species (ROS) on human health, it is important to study the action of antioxidants, since their main function is in defense of ROS to protect the cellular homeostatic balance (Azofefifa et al., 2016). Therefore, an interest to study the antioxidant peptides continue nowadays (Zeng et al., 2017).

\footnotetext{
${ }^{*}$ Corresponding author:

Efigenia Montalvo González, Laboratorio Integral de Investigación en Alimentos. Instituto Tecnológico de Tepic. Av Tecnológico No. 2595, Lagos del Country. Tepic, Nayarit, Mexico. CP 63175. E-mail: efimontalvo@gmail.com; emontalvo@ittepic.edu.mx.
}

Received: 25 July 2017 ; $\quad$ Accepted: 29 January 2018 
According to Rajapakse et al. (2005) and Xiong (2010) the presence of cysteine, methionine, tyrosine, phenylalanine, tryptophan and proline in BP is associated with their AOX as scavenging free radicals; meanwhile the presence of lysine, arginine, glutamine, aspartic acid, threonine and phosphorylated serine in BP are associated with their AOX as metal quelators.

Bertucci et al. (2015) reported a high AOX by ABTS assay in whey protein hydrolysates, and similar data by Abdel-Hamid et al. (2017) were found in BP derived from enzymatic hydrolysis of buffalo milk proteins. Kumar et al. (2016) mentioned that the AOX (ABTS, DPPH and FRAP assays) of camel milk casein was significantly high in protein hydrolysates and their peptide fractions. Liu et al. (2015) found that the peptide fractions from egg white protein showed a higher AOX than hydrolysates with ORAC method.

The proteases extracted from Bromelia karatas (B. karatas) and Bromelia pinguin (B. pinguin) fruits have not been used to generate $\mathrm{BP}$, but they have a wide perspective due to their high hydrolytic activity (Moreno-Hernández et al., 2017). The aim of this work was to evaluate the AOX of protein hydrolysates and biopeptide fractions from hydrolysis of egg, milk and soy proteins with proteases extracted from B. pinguin and B. karatas fruits.

\section{MATERIAL AND METHODS}

\section{Chemicals}

Sodium dodecyl sulfate (SDS) and polyacrylamide were purchased from Bio-Rad Laboratories (Hercules, California, USA). Bovine serum albumin (BSA), bromelain (EC 3.4.22.32), tyrosine, Coomassie Brilliant Blue, ethane-1,2-diyldinitrilo tetra acetic acid (EDTA), 2,4,6tris (2-pyridyl)-S-triazine (TPTZ), 2,2-azinobis-(3ethylbenzothiazoline-6-sulphonic) acid di-ammonium salt (ABTS) and 2,2'-azobis (2-amidinopropane) dihydrochloride (AAPH) were obtained from Sigma-Aldrich Co. (St. Louis, MO, USA). All other reagents used were analytical grade.

\section{Raw materials}

Ripe fruits were collected from wild species of B. pinguin and B. karatas in Santiago Ixcuintla, Nayarit, Mexico on November 2015. The fruits were peeled and the seeds were removed. The pulps had a $\mathrm{pH}$ of 3.14-3.67, total soluble solids of $12.4-16.72^{\circ}$ Brix, titratable acidity of $2.49-3.35 \%$, and total proteins of $7.22-8.047 .22 \%$. They were frozen and stored at $-80^{\circ} \mathrm{C}$ until their analysis.

Milk and soy proteins were purchased from Nestlé S.A. de C.V. (Mexico City, Mexico), and egg ovalbumin was obtained from HYCEL de Mexico S.A de C.V. (Mexico City, Mexico).

Emir. J. Food Agric • Vol $30 \bullet$ Issue 2 • 2018

\section{Partial purification of proteases}

Crude enzyme extracts (CEEs) from B. karatas and $B$. pinguin fruits were obtained with phosphate-cysteine buffer ( $\mathrm{pH}$ 6.1) and $\mathrm{Na}_{2} \mathrm{~S}$ buffer ( $\mathrm{pH}$ 6.1), respectively (Meza-Espinoza et al., 2017). The partial purification was performed at $4^{\circ} \mathrm{C}$. CEEs were filtered and centrifuged $\left(6,000 x g, 15 \mathrm{~min}, 4^{\circ} \mathrm{C}\right)$. Cold acetone $\left(-20^{\circ} \mathrm{C}, 1: 1 \mathrm{v} / \mathrm{v}\right)$ was added to the supernatants of CEEs. The samples were stored at $-20^{\circ} \mathrm{C}$ for $1 \mathrm{~h}$. The precipitate was eliminated. Two volumes of cold acetone were slowly added to the supernatants. The precipitated proteases were centrifuged at $6,000 \mathrm{xg}$ for $10 \mathrm{~min}$ at $4^{\circ} \mathrm{C}$. The proteases pellet were frozen at $-80^{\circ} \mathrm{C}$ and freeze-dried (LABCONCO, Model 77522020 , Kansas, USA) at $-50^{\circ} \mathrm{C}$ for $12 \mathrm{~h}$ under $12 \mathrm{~Pa}$.

\section{Production of crude hydrolysates}

The egg ovalbumin, milk and soy protein solutions $(10 \mathrm{~g} / \mathrm{L})$ were prepared with $0.1 \mathrm{M}$ phosphate buffer at pH 7.0 (Natalucci et al., 1996). The hydrolysis reaction was performed according to Kim et al. (1990) with some modifications of Meza-Espinoza et al. (2017). The crude hydrolysates $(\mathrm{CH})$ were freeze-dried and stored at $-80^{\circ} \mathrm{C}$ until analysis.

\section{Separation of biopeptide fractions}

The CH were separated by ultrafiltration (Cho et al., 2004), with an ultrafiltration unit (Millipore mini system 8050, Bedford, MA) and using membranes with molecular weight cut-off (MWCO) of 30, 10, 5 and $1 \mathrm{kDa}$. The filtration system was set at $1379 \mathrm{kPa}$ of pressure and $4^{\circ} \mathrm{C}$. Four biopeptide fractions (BPFs) were obtained: $\mathrm{F} 1(\leq 1 \mathrm{kDa})$, $\mathrm{F} 2(\leq 5 \mathrm{kDa}), \mathrm{F} 3(\leq 10 \mathrm{kDa})$ and $\mathrm{F} 4(\leq 30 \mathrm{kDa})$. The protein content in the BPFs was performed by Bradford method (1976). A bovine serum albumin (BSA) standard was used for the quantification. The BPFs were freeze-dried and stored at $-80^{\circ} \mathrm{C}$ until their analysis.

\section{Determination of proteolytic Activity}

The proteolytic activity was determined using Natalucci et al., method (1996) with some modifications of MezaEspinoza et al. (2017). One activity unit (U) was defined as the millimoles of tyrosine per minute under the above assay conditions. The specific activity (EA) was calculated as $\mathrm{U} / \mathrm{mg}$ of protein.

\section{Determination of degree of hydrolysis (DH) and total soluble biopeptides (TSP)}

DH and TSP were calculated as it was reported by MezaEspinoza et al. (2017).

\section{Determination of antioxidant capacity}

2,2'azino-bis-3-ethylbenzthiazoline-6-sulphonic acid (ABTS) radical scavenging assay

The $\mathrm{ABTS}^{-+}$radical scavenging assay was realized using the methods of Re et al. (1999) and Álvarez-Parrila 
et al. (2011). The results were reported in mmol Trolox (6-hydroxy-2,5,7,8-tetramethylchromane-2-carboxylic acid) equivalents (TE) per gram of dry weight (DW) of sample (mmol TE/g DW).

\section{Ferric reducing antioxidant power (FRAP)}

The methods of Benzie and Strain (1996) and ÁlvarezParrilla et al. (2011), were used to measure antioxidant power. Results were expressed as mmol TE/g DW.

\section{Oxygen radical absorbance capacity (ORAC)}

The ORAC assay was determined according to Liu et al. (2015). The results were reported in $\mu \mathrm{M} \mathrm{TE} / \mathrm{ml}$.

\section{Statistical analysis}

Data were analyzed by ANOVA $(\mathrm{p}<0.05)$ using STATISTICA software (v.10 StatSoft, Tulsa, Oklahoma, USA). Multiple means comparisons were performed with Tukey's test $(\alpha=0.05)$. Each measurement was replicated at least three times.

\section{RESULTS AND DISCUSSION}

\section{Proteolytic activity}

The proteolytic activity of B. karatas and B. pinguin proteases was 10.0 and $22.83 \mathrm{U} / \mathrm{mg}$ protein, respectively. These results confirmed that isolated proteases had proteolytic activity, although the highest activity was observed in B. pinguin proteases. It has been reported that the different genetic characteristics of each fruit species synthetize endopeptidases with different structure and catalytic activities (Headon and Walsh, 1994). B. karatas proteases had the lowest enzymatic activity; but the proteolytic activity was similar than purified B. pinguin proteases (7.11 to $11.0 \mathrm{U} / \mathrm{mg}$ protein) of fruits harvested in Cuba (Payrol et al., 2005, 2008).

\section{Degree of hydrolysis (DH)}

The DH (Fig. 1) was carried out until 35 min since that after this time there was no significant difference $(p<0.05)$. In all substrates, the $B$. pinguin proteases caused the highest $\mathrm{DH}$. The egg ovalbumin and milk proteins were hydrolyzed until $61-68 \%$ with the B. pinguin proteases at $30 \mathrm{~min}$ (Fig. $1 \mathrm{a}$ and 1b), while the soy protein was hydrolyzed until $81 \%$ in the same time (Fig. 1c). The bromelain showed a DH lower than the B. pinguin proteases but higher than the B. karatas proteases in all substrates. The egg ovalbumin, milk and soy proteins were hydrolyzed with bromelain in 55, 62 and $77 \%$, respectively in $35 \mathrm{~min}$; while the B. karatas proteases hydrolyzed the same substrates in 50,55 and 73\% in the same time, respectively.

$\mathrm{DH}$ is the percentage of broken peptide bonds in ratio of the original protein, which is an important indicator of final characteristics of protein hydrolysates. The final $\mathrm{DH}$ is determined by process conditions such as substrate concentration, nature of the enzyme, ratio enzymesubstrate, incubation time, $\mathrm{pH}$ and temperature (GarcíaMoreno et al., 2016; Zarei et al., 2016). The B. pinguin proteases had a higher activity than B. karatas proteases. Moreno-Hernández et al. (2017) reported a presence of cysteine and serine proteases in B. pinguin fruits. The soy substrate was more hydrolyzed by both proteases, probably because it is a plant substrate with a chemical structure easier to hydrolyze.

The DH reported in this study was also higher than what was reported by Oseguera-Toledo et al. (2015). These authors studied the hydrolysis of bean protein with bromelain, reporting only a DH of $28-30 \%$. On the other hand, Muhammad Auwal et al. (2017) found a DH of $44.59 \%$ in stone fish with bromelain. It is feasible to generate different sizes of peptides during hydrolysis, but all is in function of the specificity of the used enzyme and relative rates of hydrolysis of the peptide bond and mode of action of endo or exo proteinases. The nature of the hydrolysates obtained in the study is more related to exo proteinases (serine and cysteine proteases) (MorenoHernández et al., 2010). Thus, the nature of the enzyme will influence the $\mathrm{DH}$ and the structure of produced peptides (García-Moreno et al., 2017).

\section{Total soluble biopeptide content (TSP)}

There was a significant effect $(p<0.05)$ of the protease type, substrate and hydrolysis time in the TSP (Fig. 2). In all treatments, the TSP content increased with respect to time. In the egg ovalbumin hydrolysates obtained with B. pinguin proteases or bromelain, the TSP were 335.1 and $309.3 \mu \mathrm{g} / \mathrm{ml}$, respectively; meanwhile in the egg ovalbumin hydrolysates obtained with $B$. karatas proteases, the TSP was $140 \mu \mathrm{g} / \mathrm{ml}$ (Fig. 2a). The B. pinguin proteases also caused higher TSP content in milk hydrolysates than the bromelain or B. karatas proteases, where lower TPS values were found (Fig. 2b). On the other hand, in the soy hydrolysates (Fig. 2c) there were 981.3, 767.7 and 495.2 $\mu \mathrm{g} / \mathrm{ml}$ of TSP when the B. pinguin proteases, bromelain and B. karatas proteases were used, respectively. The TSP content coincided with the $\mathrm{DH}$ of each substrate, and therefore it was confirmed that the B. pinguin proteases are more effective to obtain TSP of different substrates than the other evaluated proteases.

There were no reports on the use of B. pinguin and B. karatas proteases in the production of soluble peptides. However, Bah et al. (2015) reported a low production of peptides from deer, sheep and pig blood when papain and bromelain were used. They concluded that the animal proteins are more difficult to hydrolyze with specific plant proteases, 


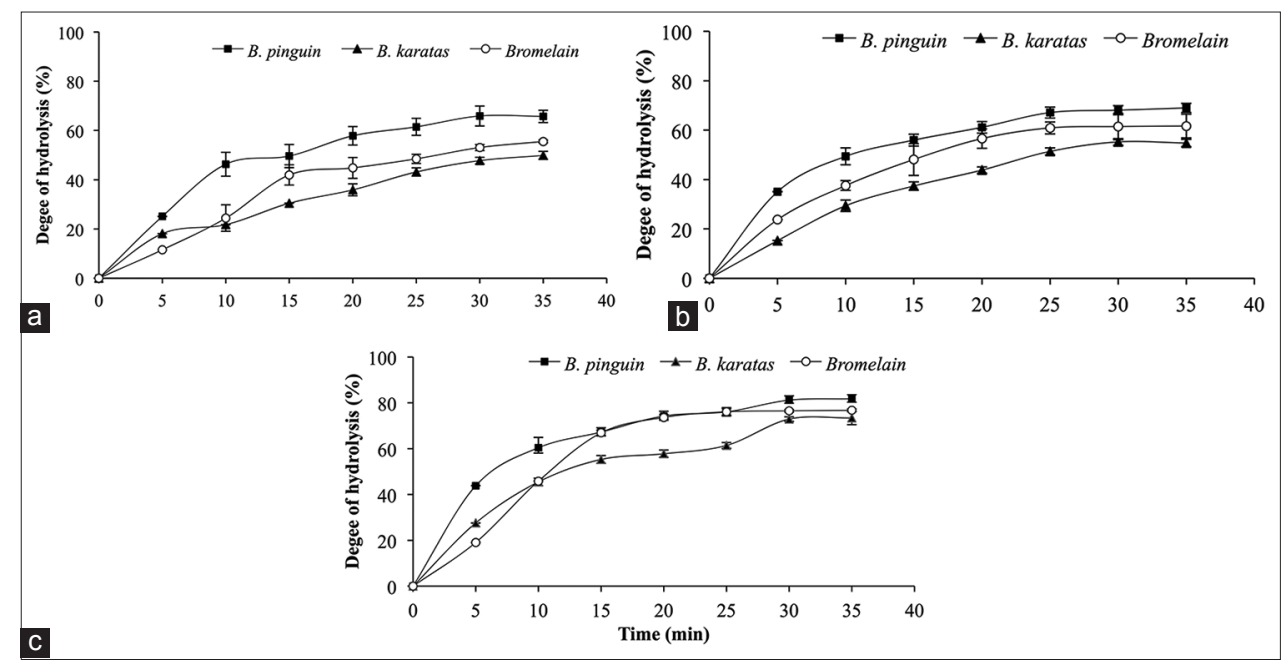

Fig 1. Degree of hydrolysis of egg ovalbumin (a), milk (b) and soy (c) proteins using partially purified proteases from B. pinguin and B. karatas fruits and bromelain standard.

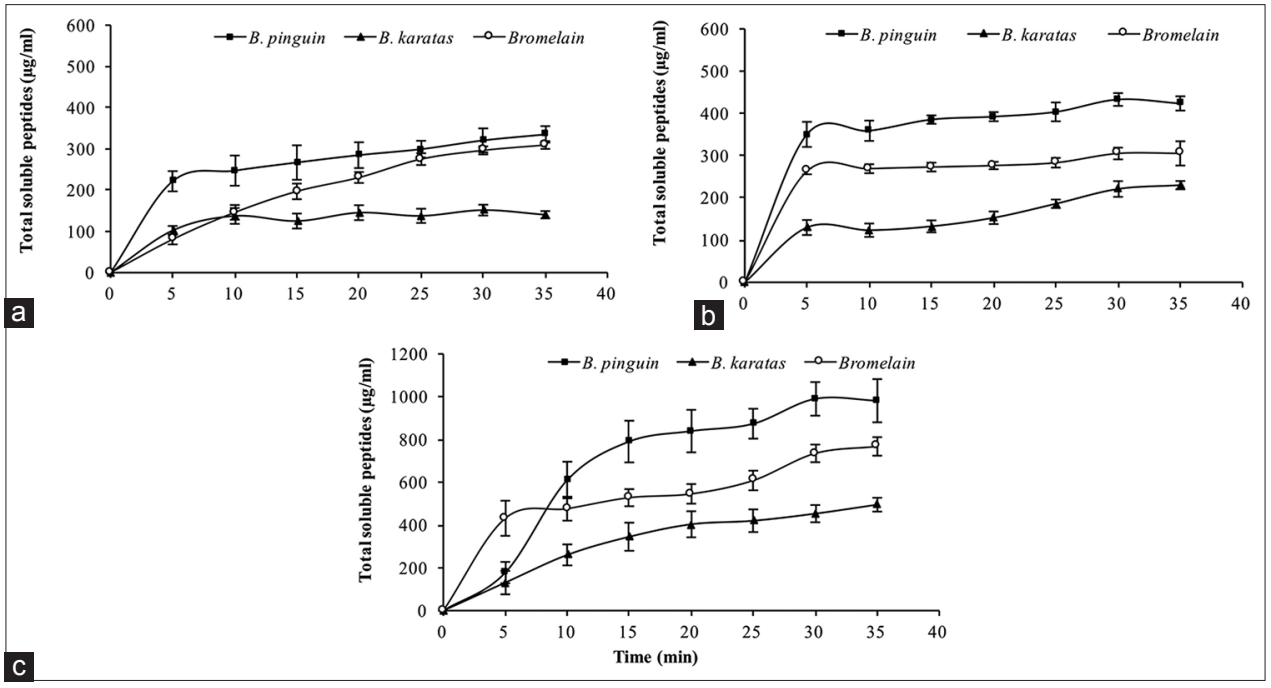

Fig 2. Total soluble peptides in crude hydrolysates from egg ovalbumin (a), milk (b) and soy (c) proteins using partially purified proteases from B. pinguin, B. karatas and bromelain standard.

and therefore it is necessary to continue studying more plant proteases such as the proteases in this study and enzyme complexes. On the other hand, Michelke et al. (2017) reported that the soy, milk and egg proteins are an excellent source of BP although they have been hydrolyzed with microbial enzymes. Therefore, the use of plant proteases such as B. pinguin and B. karatas proteases can be a good alternative because they can resist a wide range of $\mathrm{pH}$ and temperatures that microbiological enzyme can no resist (Moreno-Hernández et al., 2017).

\section{Antioxidant capacity (AOX) of crude hydrolysates (CH)}

The AOX was higher in all $\mathrm{CH}$ than the proteins without to hydrolyze (Fig. 3). The highest AOX by ABTS assay was recorded for the soy $\mathrm{CH}$ followed by the egg ovalbumin $\mathrm{CH}$ (17.76 and $16.13 \mathrm{mmol} \mathrm{TE} / \mathrm{g}$, respectively), when the $B$. pinguin (Fig. 3a) and B. karatas (Fig. 3b) proteases hydrolyzed the substrate during $60 \mathrm{~min}$. In the milk $\mathrm{CH}$, the AOX was lower with values between 10.17 and $11.95 \mathrm{mmol} \mathrm{TE} / \mathrm{g}$ without significant differences $(\mathrm{p}>0.05)$, when both plant proteases were used. FRAP is a measurement of the ability of compounds to reduce ferric iron (III)/ ferricyanide complex to ferrous iron (II). The FRAP capacity was also higher in the soy $\mathrm{CH}$ when the B. pinguin or B. karatas (8.57 and 8.89 $\mathrm{mmol} \mathrm{TE} / \mathrm{g}$, respectively) proteases were used (Fig. 3c) with 60 min of hydrolysis, followed by the egg ovalbumin $\mathrm{CH}$ (Fig. 3d); whereas the milk $\mathrm{CH}$ recorded the lowest FRAP capacity $(5.70-6.26 \mathrm{mmol} \mathrm{TE} / \mathrm{g})$ in all treatments. The results of the ORAC assay are shown in Fig. 3e and 3f. They showed that the soy and milk $\mathrm{CH}$ had significantly $(\mathrm{p}<0.05)$ higher ORAC values (116.86-126.51 $\mu \mathrm{M} \mathrm{TE} / \mathrm{ml}$ ) for 30 or $60 \mathrm{~min}$ of hydrolysis than the egg ovalbumin $\mathrm{CH}(109.54-112.57 \mu \mathrm{M}$ $\mathrm{TE} / \mathrm{ml}$ ) with both plant proteases. 

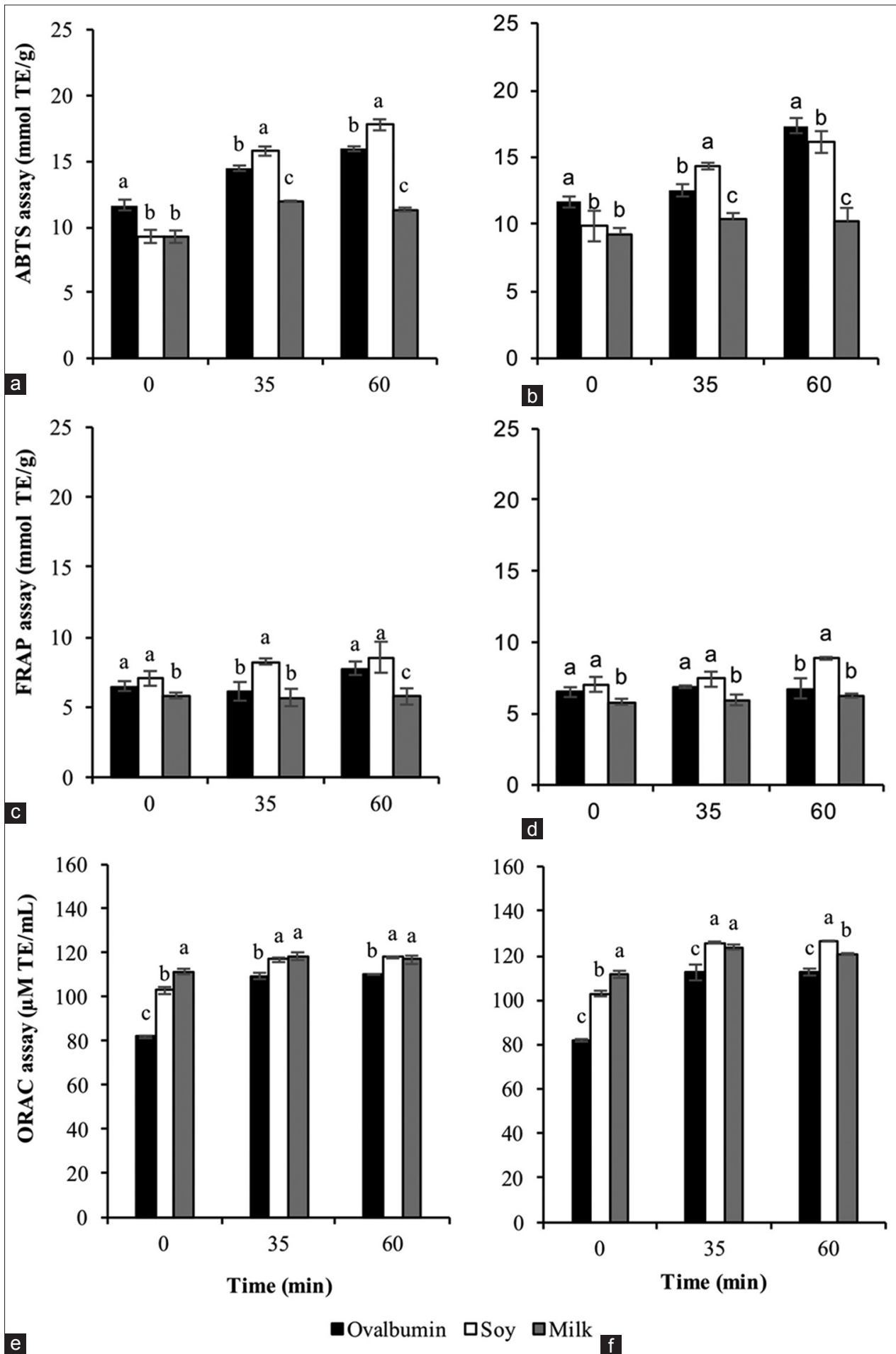

Fig 3. Antioxidant capacity by the ABTS, FRAP and ORAC assays of crude hydrolysates from egg ovalbumin, soy and milk proteins using partially purified proteases from $B$. pinguin $(a, c, e)$ and $B$. karatas fruits $(b, d, f)$.

Only plant proteases such as bromelain and papain have been proved to generate hydrolysates. Bah et al. (2016) reported that there was a high AOX (using the FRAP or ORAC assays) in the cattle plasma hydrolysates when they were obtained with papain after $4 \mathrm{~h}$. The data were similar when fungal proteases were used. The same authors concluded that the red blood cell fractions separated from deer, sheep, pig, and cattle abattoir-sourced blood and obtained by hydrolysis using papain, had a reducing power (FRAP) and an oxygen radical absorbance capacity (ORAC) higher than those generated with fungal proteases or bromelain. Therefore, with the obtained results the Bromelia proteases evaluated in this study could be an alternative to produce $\mathrm{BP}$ with $\mathrm{AOX}$. 
Soy substrate showed the highest DH and TSP content followed by egg ovalbumin and milk proteins, and therefore it is probable that the high AOX of the soy $\mathrm{CH}$ might be due to the antioxidant action of all peptides (smaller or larger), also the TSP were found in highest content in $\mathrm{CH}$ (Kumar et al., 2016). In the same way, the high activity of the soy $\mathrm{CH}$ might be because of there were peptides with different molecular size and different amino acids sequence, therefore a different structural functionality, which may have synergistic effects in the scavenging of free radicals (Neves et al., 2017).

The difference in the free radical reducing and scavenging capacity of $\mathrm{CH}$ dependent of protein hydrolysis with different enzymes, which each one can be produce $\mathrm{CH}$ peptides with different amino acid sequence. Klompong et al. (2007) mentioned that the enzymes used for hydrolysis and type of proteins play a vital role in the generation of peptides with antioxidant power. The differences in AOX of $\mathrm{CH}$ might be due to the specific peptide and the amino acid composition (Wu et al., 2003). The AOX presented by antioxidant peptides depend on some factors such as nature of the substrate, affinity of the solvent, and purity of the substrate (Mazorra-Manzano et al., 2017). Therefore, based on the AOX assays described above, we can indicate that the soy $\mathrm{CH}$ obtained with the B. pinguin and B. karatas proteases exerted the higher AOX in all oxidation systems, as it could donate hydrogen and scavenge free radicals. Kumar et al. (2016) reported similar data with lower AOX in camel milk peptide fractions of $<1 \mathrm{kDa}$ using the ABTS assay. Sudhakar and Nazeer (2015) suggested that the AOX of peptides depend not only on their amino acid composition, but also on the size and functional specific groups of sequence and hydrophobicity. However, in this work it was demonstrated that the enzyme type also had a significant effect $(\mathrm{p}<0.05)$ on their AOX.

\section{Antioxidant capacity (AOX) of biopeptide fractions (BPFs)}

The results of AOX using the ABTS assay with the two enzymes are presented in Fig. 4a. Among BPFs from egg ovalbumin, milk and soy obtained with the $B$. pinguin proteases (Fig. 4a), the highest AOX was reported for F4 (20.46, 23.39 and $18.46 \mathrm{mmol} \mathrm{TE} / \mathrm{g}$, respectively) followed by F3, F2 and F1. The ABTS capacity of F2 from egg ovalbumin and soy was comparable to F3 ( $p>0.05)$. In the BPFs obtained with the B. karatas proteases (Fig. 4b), F3 from soy had the highest ABTS capacity (17.96 mmolTE/g), followed by F3 from egg ovalbumin (12.89 mmol TE/g) and milk $(9.07 \mathrm{mmol}$ TE/g). However, the ABTS capacity was low in all fractions F1 and F2; also in F4 from egg ovalbumin.

In Fig. 4c, the FRAP capacity of F1 from soy was high (21.23 mmol TE/g), followed by F2 from egg ovalbumin
(15.23 mmol TE/g), and F3 from soy $(11.40 \mathrm{mmol}$ TE/g). Nevertheless, among the fractions obtained with the B. karatas proteases (Fig. 4d), F2 from egg ovalbumin and soy had the highest FRAP capacity (49.22 and 32.73 mmol TE/g, respectively) followed by F1 of the same BPFs. On the other hand, the results showed that all the fractions obtained with the B. pinguin proteases (Fig. 4e) had the significantly highest ORAC values (110.42-121.55 $\mu \mathrm{M} \mathrm{TE} / \mathrm{ml})(\mathrm{p}<0.05)$, although it was observed that the BPFs from egg ovalbumin and soy had a higher AOX than milk BPFs. When BPFs were obtained with the $B$. karatas proteases (Fig. 4f), the ORAC values of all soy peptide fractions were 129.64 to $135.73 \mu \mathrm{M} \mathrm{TE} / \mathrm{ml}$. However, the egg ovalbumin and milk peptide fractions registered ascendant ORAC values directly in ratio with their molecular weight. F4 from egg ovalbumin and milk had the highest ORAC capacity of 126.29 and $134.84 \mu \mathrm{M}$ $\mathrm{TE} / \mathrm{ml}$, respectively.

BPFs with the highest molecular weight had a high antiradical scavenging capacity and their efficiency probably depended upon the number of aromatic amino acids, and their hydrophobic nature (Cian et al., 2015).

The BPFs with low molecular weight had the higher AOX with the FRAP assay than with the ABTS assay. Therefore, is it possible that the smaller peptides have a higher free radical reducing capacity than these with high molecular weight. The metal ion chelation is effective when exist histidine at the N-terminal of peptide sequence (Chen et al., 1998). Also, the presence of acidic and/or basic amino acids in the peptide sequence play an important role in the chelation of metal ions by the carboxyl and amino groups in their structure (Rajapakse et al., 2005; Suetsuna et al., 2000). Therefore, based on the chelation ability and the observed high radical scavenging might be due to the combine effects of radical scavenging and ion chelation capacity of BPFs.

In general, all BPFs showed good oxygen radical absorbance capacities. These results are similar as those reported by Liu et al. (2015), who reported that PF of 6-7 $\mathrm{kDa}$ showed the best oxygen radical absorbance capacity. Therefore, the BPFs from soy, egg ovalbumin and milk have the capacity to neutralize peroxyl radicals.

\section{CONCLUSIONS}

The results in this study demonstrated that an extensive hydrolysis (DH between 50 to $81 \%$ ) was achieved by the proteolysis of egg ovalbumin, milk and soy substrates with B. pinguin and B. karatas proteases, which resulted in the generation of hydrolysates and biopeptide fractions with 


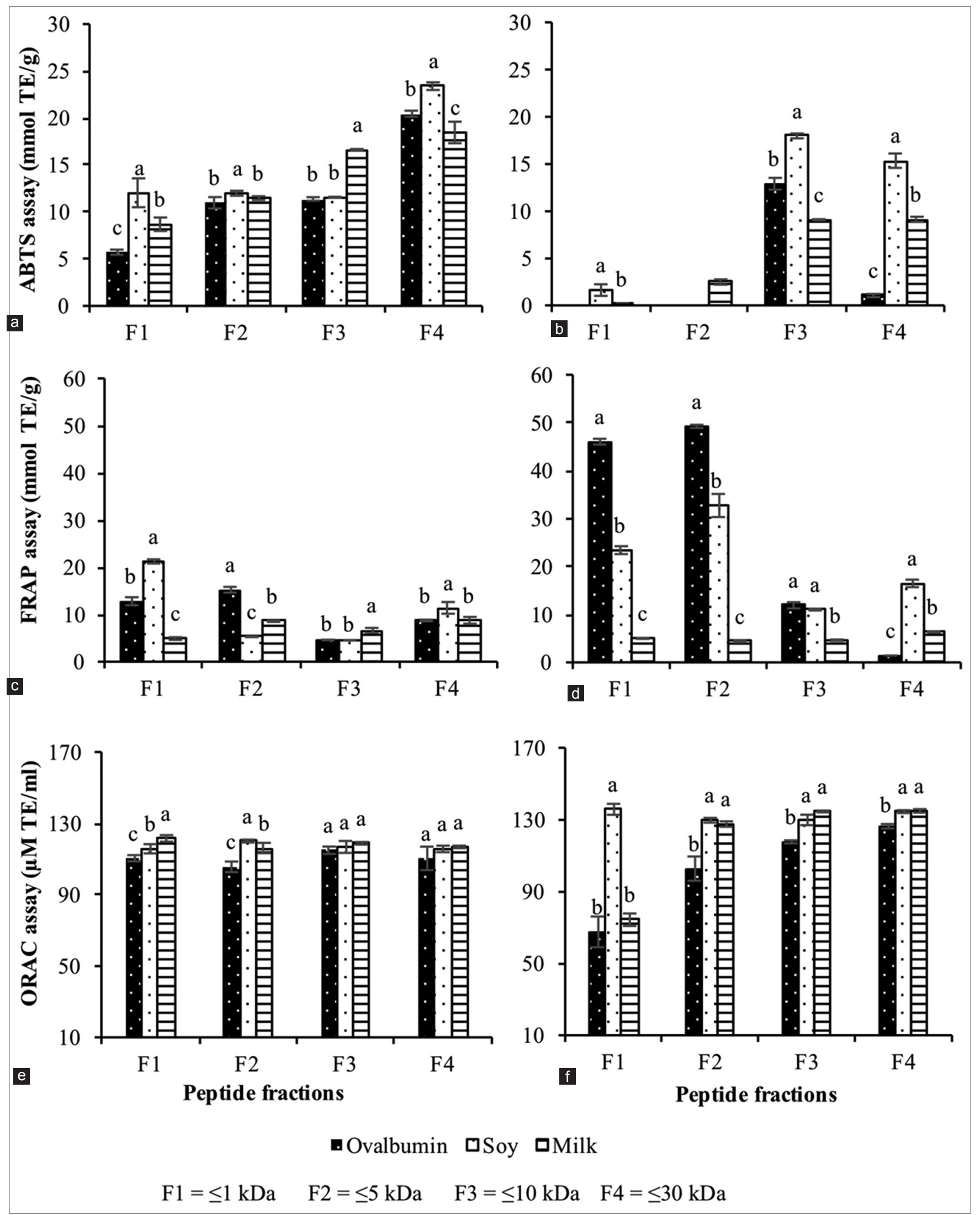

Fig 4. Antioxidant capacity (AOX) using the ABTS, FRAP and ORAC assays, for peptide fractions from egg ovalbumin, soy and milk proteins using partially purified proteases from $B$. pinguin $(a, c, e)$ and $B$. karatas fruits $(b, d, f)$. 
in vitro antioxidant capacity by different assays. Further studies are needed to validate the potential application of these proteases in the obtaining the hydrolysates/peptides with others biological activities.

\section{ACKNOWLEDGEMENTS}

The authors acknowledge the funding obtained from Tecnologico Nacional de Mexico (No. Grant number 5613.15-P).

\section{Author's contribution}

All authors contributed substantially to the writing and revising of the manuscript. LME and EMG (corresponding author) designed the work, acquired, analyzed, and interpreted the data. LME, EGTP, AFGC and EMG obtained protease extracts and protein fractions and statistical analysis. LME, AHM and SGSA developed and standardized the antioxidants assays. LME, MLGM and EMG standardized the degree of hydrolysis methods. EMY and BVC critically reviewed, corrected and edited the manuscript.

\section{REFERENCES}

Abdel-Hamid, M., J. Otte, C. de Gobba, A. Osman and E. Hamad. 2017. Angiotensin I-converting enzyme inhibitory activity and antioxidant capacity of bioactive peptides derived from enzymatic hydrolysis of buffalo milk proteins. Int. Dairy J. 66: 91-98.

Álvarez-Parrilla, E., De La Rosa, L. A., Armarowics, R., Shahidi, F. 2011. Antioxidant activity of fresh and processed Jalapeño and Serrano peppers. J. Agric. Food Chem. 59: 163-173.

Azofeifa, G., Quesada, S., Navarro, L., Hidalgo, O., Portet, K., Pérez, A. M., Vaillant, F., Poucheret, P., Michel, A. 2016. Hypoglycaemic, hypolipidaemic and antioxidant effects of blackberry beverage consumption in streptozotocin-induced diabetic rats. J. Funct. Foods. 26: 330-337.

Bah, C. S., A. E. D. A. Bekhit, A. Carne and M. A. McConnell. 2015. Production of bioactive peptide hydrolysates from deer, sheep and pig plasma using plant and fungal protease preparations. Food Chem. 176: 54-63.

Bah, C. S., A. E. D. A. Bekhit, M. A. McConnell and A. Carne. 2016. Generation of bioactive peptide hydrolysates from cattle plasma using plant and fungal proteases. Food Chem. 213: 98-107.

Benzie, I. F. and J. J. Strain. 1996. The ferric reducing ability of plasma (FRAP) as a measure of "antioxidant power": The FRAP assay. Anal. Biochem. 239: 70-76.

Bertucci, J. I., C. S. Liggieri, M. L. Colombo, S. E. V. Cavalli and M. A. Bruno. 2015. Application of peptidases from Maclura pomifera fruit for the production of active biopeptides from whey protein. LWT-Food Sci. Technol. 64: 157-163.

Bradford, M. M. 1976. A rapid and sensitive method for the quantitation of microgram quantities of protein utilizing the principle of protein-dye binding. Anal. Biochem. 72: 248-254.

Chen, H. M., K. Muramoto, F. Yamauchi, K. Fujimoto and K. Nokihara. 1998. Antioxidative properties of histidine-containing peptides designed from peptide fragments found in the digests of a soybean protein. J. Agric. Food Chem. 46: 49-53.
Cho, M. J., N. Unklesbay, F. H. Hsieh and A. D. Clarke. 2004. Hydrophobicity of bitter peptides from soy protein hydrolysates. J. Agric. Food Chem. 52: 5895-5901.

Cian, R. E., J. Vioque, and S. R. Drago. (2015). Structure-mechanism relationship of antioxidant and ACE I inhibitory peptides from wheat gluten hydrolysate fractionated by $\mathrm{pH}$. Food Res. Int. 69: 216-223.

García-Moreno, P. J., R. Pérez-Gálvez, F. J. Espejo-Carpio, C. Ruiz-Quesada, A. I. Pérez-Morilla, O. Martínez-Agustín, A. Guadix and E. M. Guadix. (2017). Functional, bioactive and antigenicity properties of blue whiting protein hydrolysates: Effect of enzymatic treatment and degree of hydrolysis. J. Sci. Food Agric. 97(1), 299-308.

Headon, D.R. and G. Walsh. 1994. The industrial production of enzymes. Biotechnol. Adv. 12: 635-646.

Kim, S. Y., P. W. Park and K. C. Rhee. 1990. Functional properties of proteolytic enzyme modified soy protein isolate. J. Agric. Food Chem. 38: 651-656.

Klompong, V., S. Benjakul, D. Kantachote and F. Shahidi. 2007. Antioxidative activity and functional properties of protein hydrolysate of yellow stripe trevally (Selaroides leptolepis) as influenced by the degree of hydrolysis and enzyme type. Food Chem. 102: 1317-1327.

Kumar, D., M. K. Chatli, R. Singh, N. Mehta and P. Kumar. 2016. Antioxidant and antimicrobial activity of camel milk casein hydrolysates and its fractions. Small Rumin. Res. 139: 20-25.

Lafarga, T. R. E. Aluko, D. K. Rai, P. O'Connor and M. Hayes. 2016. Identification of bioactive peptides from a papain hydrolysate of bovine serum albumin and assessment of an antihypertensive effect in spontaneously hypertensive rats. Food Res. Int. 81: 9199.

Liu, J., Y. Jin, S. Lin, G. S. Jones and F. Chen. 2015. Purification and identification of novel antioxidant peptides from egg white protein and their antioxidant activities. Food Chem. 175: 258266.

Marques, M. R., G.G. Fontanari, D.C. Pimenta, R. M. Soares-Freitas and J. A. G. Arêas. 2015. Proteolytic hydrolysis of cowpea proteins is able to release peptides with hypocholesterolemic activity. Food Res. Int. 77: 43-48.

Mazorra-Manzano, M. A., Ramírez-Suarez, J. C., \& Yada, R. Y. (2017). Plant proteases for bioactive peptides release: A review. Critical Reviews in Food Science and Nutrition. DOI: 10.1080/10408398.2017.1308312

Michelke, L., A. Deussen, P. Dieterich and M. Martin. 2017. Effects of bioactive peptides encrypted in whey, soy and rice proteins on local and systemic angiotensin-converting enzyme activity. J. Funct. Foods. 28: 299-305.

Moreno-Hernández, J. M., X. D. Hernández-Mancillas, E. L. C. Navarrete, M. Á. Mazorra-Manzano, I. Osuna-Ruiz, V. A. Rodríguez-Tirado and J. A. Salazar-Leyva. 2017. Partial Characterization of the proteolytic properties of an enzymatic extract from "Aguama" Bromelia pinguin L. fruit grown in Mexico. Appl. Biochem. Biotechnol. 182: 181-196.

Muhammad Auwal, S., M. Zarei, A. Abdul-Hamid and N. Saari. (2017). Optimization of bromelain-aided production of angiotensin i-converting enzyme inhibitory hydrolysates from stone fish using response surface methodology. Mar. Drugs, 15(4), 104.

Natalucci, C. L., A. Brullo, L. M- I. López, R.M. Hilal and N. O. Caffini. 1996. Macrodontain, a new protease isolated from fruits of Pseudananas macrodontes (Morr.) Harms (Bromeliaceae). J. Food Biochem. 19: 443- 454.

Neves, A. C., P. A. Harnedy, M. B. O'Keeffe and R. J. FitzGerald. 2017. Bioactive peptides from Atlantic salmon (Salmo salar) 
with angiotensin converting enzyme and dipeptidyl peptidase IV inhibitory, and antioxidant activities. Food Chem. 218: 396-405.

Oseguera-Toledo, M. E., E. G. de Mejia and S. L. Amaya-Llano. 2015. Hard-to-cook bean (Phaseolus vulgaris L.) proteins hydrolyzed by alcalase and bromelain produced bioactive peptide fractions that inhibit targets of type-2 diabetes and oxidative stress. Food Res. Int. 76: 839-851.

Payrol, J.A., W. D. Obregón, C. L. Natalucci and N. O. Caffini. 2005. Reinvestigation of the proteolytically active components of Bromelia pinguin fruit. Fitoterapia. 76: 540-548.

Payrol, J. A., W. D. Obregón, S. A. Trejo and N. O. Caffini. 2008. Purification and characterization of four new cysteine endopeptidases from fruits of Bromelia pinguin L. grown in Cuba. The Protein J. 27: 88-96.

Przybylski, R., L. Firdaous, G. Châtaigné, P. Dhulster, and N. Nedjar. 2016. Production of an antimicrobial peptide derived from slaughterhouse by-product and its potential application on meat as preservative. Food Chem. 211: 306-313.

Rajapakse, N., E. Mendis, W. K. Jung, J. Y. Je and S. K. Kim. 2005. Purification of radical scavenging peptide from fermented mussel sauce and its antioxidant properties. Food Res. Int. 38: 175-182.

Re, R., N. Pellegrini, A. Proteggente, A. Pannala, M. Yang and C. Rice-Evans. 1999. Antioxidant activity applying an improved ABTS radical cation decolorization assay. Free Radic. Biol. Med. 26: 1231-1237.

Sabbione, A. C., A. E. Nardo, M. C. Añón and A. Scilingo. 2016. Amaranth peptides with antithrombotic activity released by simulated gastrointestinal digestion. J. Funct. Foods. 20: 204214.

Santilli, F., D. D'Ardes and G. Davì. 2015. Oxidative stress in chronic vascular disease: From prediction to prevention. Vascul. Pharmacol. 74: 23-37.

Sila, A. and A. Bougatef. 2016. Antioxidant peptides from marine byproducts: Isolation, identification and application in food systems a review. J. Funct. Foods. 21: 10-26.
Sudhakar, S., and Nazeer, R. A. (2015). Structural characterization of an Indian squid antioxidant peptide and its protective effect against cellular reactive oxygen species. J. Funct Foods. 14: 502-512.

Suetsuna, K., H. Ukeda and H. Ochi. 2000. Isolation and characterization of free radical scavenging activities peptides from casein. J. Nutr. Biochem. 11: 128-131.

Sun, H. X., L. Q. Chen, J. Zhang and F. Y. Chen. 2014. Anti-tumor and immunomodulatory activity of peptide fraction from the larvae of Musca domestica. J. Ethnopharmacol. 153: 831-839.

Titov, E. I., N. A. Tikhomirova, I I. lonova, I. F. Gorlov, M. I. Slozhenkina, N. I. Mosolova and E. Y. Zlobina. (2016). Growth stimulating effect of bovine milk lactoferrin on dermal cells and probiotic bacteria. Emir. J. Food Agric. 28(8), 540.

Wu, H.C., H. M. Chen and C. Y. Shiau. 2003. Free amino acids and peptides as related to antioxidant properties in protein hydrolysates of mackerel (Scomber austriasicus). Food Res. Int. 36: 949-957.

Xiong, Y. L. 2010. Functions of Biologically Active proteins and peptides: Antioxidant Peptides. In: Y. Mine, E. Li-Chan and B. Jiang, editors. Bioactive Proteins and peptides as functional Foods and Nutraceuticals, lowa, US. pp. 29-42.

Zarei, M., R. Ghanbari, N., Tajabadi,, A. Abdul-Hamid, F. A. Bakar, and N. Saari. (2016). Generation, fractionation, and characterization of iron-chelating protein hydrolysate from palm kernel cake proteins. J. Food Sci. 81: C341-C347

Zeineb, J., O. Nadia, A. Isabelle, K. Touhami, D. Pascal, E. H. Halima. (2015). Camel colostrum: Nutritional composition and improvement of the antimicrobial activity after enzymatic hydrolysis. Emir. J. Food Agric. 27(4), 384.

Zeng, W. C., Q. Sun, W. H. Zhang, X. P. Liao and B. Shi. 2017. Antioxidant activity in vivo and biological safety evaluation of a novel antioxidant peptide from bovine hair hydrolysates. Process Biochem. 56: 193-198. 